\title{
Coeliac disease in infants: antibodies to deamidated gliadin peptide come first!
}

\author{
Michele Arigliani ${ }^{1 *}$ (D), Francesca Rech Morassutti ${ }^{1}$, Martina Fabris ${ }^{2}$, Paola Melli ${ }^{1}$, Elio Tonutti ${ }^{2}$ and Paola Cogo
}

\begin{abstract}
Background: The onset of coeliac disease (CD) in the first year of life is uncommon and the diagnosis can be challenging due to the suboptimal sensitivity of tissue transglutaminase antibodies (tTG) at this age and the many other possible causes of malabsorption in infants. Antibodies to deamidated gliadin peptides (anti-DGPs), especially IgG, may appear earlier than IgA anti-tTG in very young children with CD.

Case presentation: We report here on an 8-month-old child who was evaluated for failure to thrive, constipation and developmental delay. The symptoms started following gluten introduction in the diet. Laboratory tests showed high fecal elastase concentration, normal serum IgA levels with positive lgG and IgA anti-DGPs, whereas anti-tTG were not detected. The duodenal biopsy revealed a complete villous atrophy (Marsh-Oberhuber 3C). The culture of biopsy fragments in the presence of gliadin peptides did not stimulate the production of IgA anti-endomysial antibodies. Genetic testing proved the child was positive for HLA-DQ2 (DQA1*05; DQB1*02) and HLA-DQ8 (DQA1*03, DQB1*0302). Having initiated the gluten-free diet, the symptoms disappeared and the infant experienced rapid catch-up growth with normalization of psychomotor development.

Conclusions: This case report highlights the utility of anti-DGPs for screening infants with suspected CD. The pattern with positivity for IgG and IgA anti-DGPs only is rare in IgA-competent children with biopsy-proven CD. It could be explained in infancy as immaturity of the adaptive immune system.
\end{abstract}

Keywords: Coeliac disease, Anti-deamidated gliadin peptides antibodies

\section{Background}

Coeliac disease (CD) is an autoimmune disorder triggered by gluten ingestion in genetically predisposed subjects [1]. While it is know to affect around $1 \%$ of Caucasian schoolchildren, the true prevalence is probably underestimated $[2,3]$. While coeliac disease can occur at any age following gluten introduction in the diet, the onset of symptoms shortly after weaning is uncommon [4-6]. The pathogenesis of the disease depends on the presence of gliadin-reactive $\mathrm{CD} 4+\mathrm{T}$ cells in the lamina propria of the small bowel, which recognize gliadin peptides deamidated by tissue transglutaminase and bound to DQ2+ or DQ8+ antigen-presenting cells [7, 8]. The gliadine-reactive $\mathrm{CD} 4+\mathrm{T}$ cells enhance an adaptive immune response that leads to intraepithelial and lamina propria infiltration of inflammatory cells, crypt

\footnotetext{
* Correspondence: michelearigliani@gmail.com

${ }^{1}$ Department of Clinical and Experimental Medical Sciences, Unit of Pediatrics, University Hospital of Udine, Piazzale S. Maria Misericordia 1, 33100 Udine, Italy Full list of author information is available at the end of the article
}

hyperplasia, and villous atrophy [9]. Innate immunity also contributes to mucosal damage [10]. Tissue transglutaminase antibodies (tTG) are directed against the enzyme responsible for the deamidation of gliadin in the lamina propria. These antibodies perform at a lower sensitivity and specificity in children under 18 months of age compared to older subjects, the earliest tTG seropositivity being reported at the age of 12 months [11-14]. Tests for antibodies to deamidated gliadin peptides (anti-DGPs) have replaced those for anti-gliadin antibodies, as the former show higher specificity [15]. Immunoglobulin G anti-DGPs are more sensitive than IgA in the diagnosis of CD [16-19]. The combination of IgA anti-tTG and IgG anti-DGP offers the best accuracy for diagnosis of $\mathrm{CD}$ at all ages, as it increases the chances of detecting the disease in subjects with IgA deficiency [17, 20-23]. Moreover, the presence of IgG antiDGPs seems to be the best serologic marker of villous atrophy in the follow up of coeliac patients [24-26]. While in older patients IgA anti-tTG levels generally 
correlate with the severity of the duodenal lesions according to the Marsh-Oberhuber grading system [27, 28], in young children high IgG anti-DGP titres are related to severe intestinal damage [29-32].

In this article we present the unusual case of an infant who developed symptoms of CD shortly after weaning. In spite of a complete villous atrophy at biopsy, only serum anti-DGPs were increased, whereas anti-tTG and anti-endomysial antibodies were absent.

\section{Case presentation}

An 8-month-old boy was evaluated for failure to thrive and developmental delay. He was born at 38 weeks of gestational age (birth weight $4.090 \mathrm{~kg}$, above the 90th percentile). Familial and antenatal history was unremarkable; in particular there was no history of gestational diabetes nor any significant perinatal event. The patient had been exclusively breastfed for the first 5 months of life, with regular growth and psychomotor development. After weaning, at between 6 and 8 months of age, the child experienced worsening constipation, bulky stools, irritability and anorexia. The onset of symptoms had no association with any specific event. The infant was admitted to the pediatric ward of the University Hospital of Udine, Italy, when he was 8-months old. His weightfor-length was below the 3rd percentile, whereas 2 months before it was at the 25th percentile [33]. Between the 6th and 8th months he also showed developmental regression: his babbling and smiling decreased, he could no longer sit without support and became apathetic and irritable. The head circumference had increased normally since birth at around the 25th percentile. The physical examination revealed severe dystrophy, with a potbelly and wasted limbs. He appeared apathetic with little interest in things and people around him. $\mathrm{He}$ also had mild hypotonia, with decreased muscle bulk but preserved deep tendon reflexes. Laboratory tests revealed a normal full blood count. A metabolic panel showed serum albumin ( $3.6 \mathrm{~g} / \mathrm{dL} ;)$, Vitamin A $(207 \mathrm{mcg} /$ L) and total IgG (269 mg/dL) levels at the lower limit of normal. A screening for CD revealed normal IgA levels, absence of tTG antibodies but positive serum anti-DGPs (IgG $183 \mathrm{U} / \mathrm{mL}$; IgA $147 \mathrm{U} / \mathrm{mL}$; normal range < $10 \mathrm{U} /$ $\mathrm{ml}$ for both, as suggested by the manufacturer). Tissuetranglutaminase antibodies and anti-DGPs were assessed by a chemiluminescence enzyme immunoassay (Zenit$\mathrm{RA}^{\circ}$, Menarini Diagnostics, Florence, Italy). All other laboratory tests of the metabolic panel were normal (including iron levels, folic acid, vitamin D, B12, and E, thyroid-stimulating hormone, creatinine kinase, venous blood gas, lactate and ammonia levels). Fecal elastase was at a low concentration $(<100 \mathrm{mcg} / \mathrm{g})$, while fecal calprotectin concentration $\left(\right.$ IDK $^{\bullet}$ Calprotectin ELISA, Immundiagnostik, Bensheim, Germany) of $135 \mathrm{mg} / \mathrm{kg}$ was in the normal range for the patient's age [34, 35]. A normal sweat chloride test ruled out cystic fibrosis and a magnetic resonance imaging of the brain excluded structural/anatomic brain abnormalities.

An esophagogastroduodenoscopy with duodenal biopsy showed complete villous atrophy with crypt hypertrophy and more than 60 intraepithelial lymphocytes per 100 enterocytes in the duodenal mucosal, corresponding to a 3C score of the Modified Marsh (Oberhuber) classification. Antiendomysial IgA antibodies were not detected in the supernatant of duodenal mucosal fragments cultured with gliadin peptides [36]. Genetic analysis revealed the presence of HLA-DQ2 (DQA1*05; DQB1*02) and HLADQ8 (DQA1*03; DQB1*0302). Within 4 months of initiating a gluten-free diet, the child caught up with his original weight-for-age z-score, with complete normalization of neurological evaluation and laboratory parameters. Six months after the diagnosis, IgG anti-DGP were still slightly positive $(20 \mathrm{UI} / \mathrm{ml}$, normal range $<10 \mathrm{UI} / \mathrm{ml})$, while IgA anti-tTG were absent. After 6 months and for the next 2 years both DGP and tTG antibodies resulted negative.

\section{Discussion}

In this case report, the serological pattern with DGPpositive/tTG-negative antibodies in an infant was predictive of $C D$ with villous atrophy. The finding confirms evidence from literature that anti-DGPs are a sensitive marker of $\mathrm{CD}$ in very young children and may be the first CD antibodies to seroconvert $[37,38]$. This would be in accordance with the suggested pathogenesis of $\mathrm{CD}$, as the disease process seems to initiate with the T-cell responses to deamidated gliadin peptides in the intestinal mucosa [39]. However, only a minority of children with circulating $\mathrm{T}$ cells specific to deamidated gliadin will develop anti-DGPs and celiac disease. Peripheral blood Tcell responses to deamidated gliadin peptides were detectable at 9 months of age in $40 \%$ of a cohort including 300 children with HLA-associated genetic risk for CD. However only $3.1 \%$ of the cohort's subjects had developed CD by the age of 4 years, each being seropositive for IgG antiDGPs and IgA anti-tTG at the time of diagnosis [40].

Lammi et al. showed that in 35 of the 48 children with CD from the Finnish DIPP study [41], serum IgG antiDGPs preceded tTG positivity and appeared on average 1 year earlier [19]. Our patient, unlike the children with anti-DGPs seropositivity and CD described by Lammi et al. [19], never developed tTG antibodies in spite of severe gluten-sensitive enteropathy.

The positivity of serum anti-DGPs only in very young children has a poor positive predictive value for $\mathrm{CD}$ and should be considered with caution: in a retrospective analysis, Parizade found that over $60 \%$ of children under 2 years of age with DGP-positive/tTG-negative pattern (HLA 
alleles not reported) became seronegative within 1 year, without following a gluten-free diet [42]. In that study, 6 out of 12 children with only anti-DGP positivity referred for biopsy, had a diagnosis of CD [42]. In the study by Olen and colleagues, [43] villous atrophy was found only in 8 of 149 children with DGP-positivity and tTG-negativity. These findings would suggest duodenal biopsy may be indicated in infants with sole anti-DGP positivity only if they have signs/symptoms consistent with CD and positivity for HLA DQ2/DQ8, as was the case in our patient [42, 44].

The children reported here was at standard genetic risk of $C D$, given the presence of the HLA-DQ2 (DQA1*05; DQB1*02) and HLA-DQ8 (DQA1*03, DQB1*0302) [4], while in a case-control study by Megiorni et al. [45], the HLA haplotype with copresence of DQ2 and DQ8 resulted at the top of the genetic risk gradient for $\mathrm{CD}$ (risk 1:7).

The infant's fecal elastase was low, with chronic malabsorption. In subjects with villous atrophy, the mucosal damage may impair the release of enteric hormones (secretin and cholecystokinin) and cause secondary reduction of exocrine pancreatic secretion, which includes fecal elastase [46-50]. However in children with $C D$, fecal elastase concentration usually normalizes after a few months from the introduction of a gluten free diet [51], as in the case presented here.

The patient described in this paper had neurological symptoms at presentation, such as developmental delay and hypotonia. These symptoms are sometimes reported in children with onset of CD during infancy, possibly due to vitamin and micronutrient deficiency [52]. In our patient, no such nutritional deficit was identified although zinc levels, which are linked to neurocognitive delay in malnourished children, could not be investigated [53].

Timing of gluten introduction in our patient was in accordance with current international recommendations [37] and could not influence the onset of CD. However, recent evidence indicates that neither early $(<17$ weeks of life) nor delayed gluten introduction ( $>26$ weeks) is a risk factor for future CD [54].

\section{Conclusions}

This case report highlights the utility of IgG anti-DGPs for screening infants with suspected coeliac disease. Some of the children who develop $\mathrm{CD}$ at this age, might have an immature adaptive immune response with the sole production of anti-DGPs even in the presence of villous atrophy, as was the case in our patient. We suggest that the serologic pattern with DGP-positive/tTG-negative antibodies in an infant with consistent symptoms and HLA DQ2/DQ8 haplotype should prompt a duodenal biopsy to rule out $\mathrm{CD}$. Further studies are needed to provide a more detailed evaluation of this serologic pattern in IgA-competent children with celiac disease.

\section{Abbreviations}

CD: Coeliac disease; DGPs: Deamidated gliadin peptides; HLA: Human leukocytes antigen; tTG: Transglutaminase antibodies

\section{Acknowledgements \\ Not applicable. \\ Funding \\ The authors did not receive funding for this study.}

Availability of data and materials

Not applicable.

\section{Authors' contributions}

MA was an attending paediatrician. He conceptualized and drafted the initial manuscript, and subsequently reviewed and revised the manuscript. FRM conducted a literature review for this case report and reviewed and revised the manuscript. MF and ET performed laboratory analyses and reviewed and revised the manuscript. PM was an attending paediatrician. She reviewed and revised the manuscript. PC contributed to conceptualizing the case report and critically reviewed and revised the manuscript. All authors approved the final manuscript as submitted, and all agree to be accountable for all aspects of the work.

Ethics approval and consent to participate

Not applicable.

\section{Consent for publication}

Written informed consent for publication of the patient's clinical details was obtained from the parents. A copy of the consent form is available for review by the Editor of this journal.

\section{Competing interests}

The authors declare that they have no competing interests.

\section{Publisher's Note}

Springer Nature remains neutral with regard to jurisdictional claims in published maps and institutional affiliations.

\section{Author details}

'Department of Clinical and Experimental Medical Sciences, Unit of Pediatrics, University Hospital of Udine, Piazzale S. Maria Misericordia 1, 33100 Udine, Italy. ${ }^{2}$ Department of Laboratory Medicine, Institute of Clinical Pathology, University Hospital of Udine, Udine, Italy.

Received: 10 April 2017 Accepted: 3 August 2017

Published online: 10 August 2017

References

1. Zawahir S, Safta A, Fasano A. Pediatric celiac disease. Curr Opin Pediatr. 2009;21:655-60.

2. Garnier-Lengliné H, Cerf-Bensussan N, Ruemmele FM. Celiac disease in children. Clin Res Hepatol Gastroenterol. 2015;39:544-51.

3. Snyder J, Butzner JD, DeFelice AR, Fasano A, Guandalini S, Liu E, et al. Evidence-Informed Expert Recommendations for the Management of Celiac Disease in Children. Pediatrics. 2016;138:e20153147.

4. Lionetti E, Castellaneta S, Francavilla R, Pulvirenti A, Tonutti E, Amarri S, et al. Introduction of Gluten, HLA Status, and the Risk of Celiac Disease in Children. N Engl J Med. 2014:371:1295-303.

5. Saari A, Harju S, Mäkitie O, Saha M-T, Dunkel L, Sankilampi U. Systematic growth monitoring for the early detection of celiac disease in children. JAMA Pediatr. 2015;169:e1525.

6. Tanpowpong P, Broder-Fingert S, Katz AJ, Camargo CA. Age-Related Patterns in Clinical Presentations and Gluten-Related Issues Among Children and Adolescents With Celiac Disease. Clin Transl Gastroenterol. 2012;3:e9.

7. Green PHR, Cellier C. Celiac disease. N Engl J Med. 2007;357:1731-43.

8. Di Sabatino A, Corazza GR. Coeliac disease. Lancet Lond Engl. 2009;373: 1480-93.

9. Guandalini S, Assiri A. Celiac disease: a review. JAMA Pediatr. 2014;168:272-8.

10. Gianfrani $C$, Auricchio $S$, Troncone R. Adaptive and innate immune responses in celiac disease. Immunol Lett. 2005;99:141-5. 
11. Lagerqvist C, Dahlbom I, Hansson T, Jidell E, Juto P, Olcén P, et al. Antigliadin immunoglobulin A best in finding celiac disease in children younger than 18 months of age. J Pediatr Gastroenterol Nutr. 2008:47:428-35.

12. Leffler DA, Schuppan D. Update on serologic testing in celiac disease. Am J Gastroenterol. 2010;105:2520-4.

13. Giersiepen K, Lelgemann M, Stuhldreher N, Ronfani L, Husby S, Koletzko S, et al. Accuracy of diagnostic antibody tests for coeliac disease in children: summary of an evidence report. J Pediatr Gastroenterol Nutr. 2012;54:229-41.

14. Simell S, Hoppu S, Hekkala A, Simell T, Ståhlberg M-R, Viander M, et al. Fate of five celiac disease-associated antibodies during normal diet in genetically at-risk children observed from birth in a natural history study. Am J Gastroenterol. 2007;102:2026-35.

15. Vermeersch P, Geboes K, Mariën G, Hoffman I, Hiele M, Bossuyt X. Diagnostic performance of $\mathrm{lgG}$ anti-deamidated gliadin peptide antibody assays is comparable to IgA anti-tTG in celiac disease. Clin Chim Acta Int J Clin Chem. 2010;411:931-5.

16. Basso D, Guariso G, Fogar P, Meneghel A, Zambon C-F, Navaglia F, et al. Antibodies against synthetic deamidated gliadin peptides for celiac disease diagnosis and follow-up in children. Clin Chem. 2009;55:150-7.

17. Volta U, Granito A, Parisi C, Fabbri A, Fiorini E, Piscaglia M, et al. Deamidated gliadin peptide antibodies as a routine test for celiac disease: a prospective analysis. J Clin Gastroenterol. 2010;44:186-90.

18. Tonutti E, Visentini D, Picierno A, Bizzaro N, Villalta D, Tozzoli R, et al. Diagnostic efficacy of the ELISA test for the detection of deamidated anti-gliadin peptide antibodies in the diagnosis and monitoring of celiac disease. J Clin Lab Anal. 2009;23:165-71.

19. Lammi A, Arikoski P, Simell S, Kinnunen T, Simell V, Paavanen-Huhtala S, et al. Antibodies to deamidated gliadin peptide in diagnosis of celiac disease in children. J Pediatr Gastroenterol Nutr. 2015;60:626-31.

20. Villalta D, Tonutti E, Prause $C$, Koletzko S, Uhlig HH, Vermeersch $\mathrm{P}$, et al. IgG Antibodies against Deamidated Gliadin Peptides for Diagnosis of Celiac Disease in Patients with IgA Deficiency. Clin Chem. 2010;56:464-8.

21. Mozo L, Gómez J, Escanlar E, Bousoño C, Gutiérrez C. Diagnostic value of anti-deamidated gliadin peptide lgG antibodies for celiac disease in children and IgA-deficient patients. J Pediatr Gastroenterol Nutr 2012;55:50-5.

22. Pallav $\mathrm{K}, \mathrm{Xu} \mathrm{H}$, Leffler DA, Kabbani T, Kelly CP. Immunoglobulin A deficiency in celiac disease in the United States. J Gastroenterol Hepatol. 2016;31:133-7.

23. Wolf J, Hasenclever D, Petroff D, Richter T, Uhlig HH, Laaß MW, et al. Antibodies in the Diagnosis of Coeliac Disease: A Biopsy-Controlled, International, Multicentre Study of 376 Children with Coeliac Disease and 695 Controls. PLoS One. 2014;9:e97853.

24. Kaukinen K, Collin P, Laurila K, Kaartinen T, Partanen J, Mäki M. Resurrection of gliadin antibodies in coeliac disease. Deamidated gliadin peptide antibody test provides additional diagnostic benefit. Scand J Gastroenterol. 2007:42:1428-33.

25. de Chaisemartin L, Meatchi T, Malamut G, Fernani-Oukil F, Hosking F, Rault D, et al. Application of Deamidated Gliadin Antibodies in the Follow-Up of Treated Celiac Disease. PLoS One. 2015;10:e136745.

26. Monzani A, Rapa A, Fonio P, Tognato E, Panigati L, Oderda G. Use of deamidated gliadin peptide antibodies to monitor diet compliance in childhood celiac disease. J Pediatr Gastroenterol Nutr. 2011;53:55-60.

27. Marsh MN. Gluten, major histocompatibility complex, and the small intestine. A molecular and immunobiologic approach to the spectrum of gluten sensitivity ('celiac sprue'). Gastroenterology. 1992;102:330-54.

28. Oberhuber $\mathrm{G}$, Granditsch $\mathrm{G}$, Vogelsang $H$. The histopathology of coeliac disease: time for a standardized report scheme for pathologists. Eur J Gastroenterol Hepatol. 1999;11:1185-94.

29. Agardh D, Lee H-S, Kurppa K, Simell V, Aronsson CA, Jörneus O, et al. Clinical Features of Celiac Disease: A Prospective Birth Cohort. Pediatrics. 2015;135:627-34

30. Donaldson MR, Firth SD, Wimpee H, Leiferman KM, Zone JJ, Horsley W, et al. Correlation of duodenal histology with tissue transglutaminase and endomysial antibody levels in pediatric celiac disease. Clin. Gastroenterol. Hepatol Off Clin Pract J Am Gastroenterol Assoc. 2007;5:567-73.

31. Alessio MG, Tonutti E, Brusca I, Radice A, Licini L, Sonzogni A, et al. Correlation between lgA tissue transglutaminase antibody ratio and histological finding in celiac disease. J Pediatr Gastroenterol Nutr. 2012;55:44-9.

32. Amarri S, Alvisi P, De Giorgio R, Gelli MC, Cicola R, Tovoli F, et al. Antibodies to deamidated gliadin peptides: an accurate predictor of coeliac disease in infancy. J Clin Immunol. 2013;33:1027-30.

33. WHO | Weight-for-length/height tables [Internet]. WHO. [cited 2017 Jun 27]. Available from: http://www.who.int/childgrowth/standards/w f I tables_p_boys/en/
34. Li F, Ma J, Geng S, Wang J, Liu J, Zhang J, et al. Fecal Calprotectin Concentrations in Healthy Children Aged 1-18 Months. PLoS One. 2015; 10(3):e0119574. https://doi.org/10.1371/journal.pone.0119574

35. Hestvik E, Tumwine JK, Tylleskar T, Grahnquist L, Ndeezi G, Kaddu-Mulindwa $\mathrm{DH}$, et al. Faecal calprotectin concentrations in apparently healthy children aged 0-12 years in urban Kampala. Uganda: a community-based survey BMC Pediatr. 2011;11:9.

36. Carroccio A, lacono G, D'Amico D, Cavataio F, Teresi S, Caruso C, et al. Production of anti-endomysial antibodies in cultured duodenal mucosa: usefulness in coeliac disease diagnosis. Scand J Gastroenterol. 2002;37:32-8.

37. Rubio-Tapia A, Hill ID, Kelly CP, Calderwood AH, Murray JA. ACG Clinical Guidelines: Diagnosis and Management of Celiac Disease. Am J Gastroenterol. 2013;108:656-76.

38. Liu E, Li M, Emery L, Taki I, Barriga K, Tiberti C, et al. Natural history of antibodies to deamidated gliadin peptides and transglutaminase in early childhood celiac disease. J Pediatr Gastroenterol Nutr. 2007;45:293-300.

39. Castillo NE, Theethira TG, Leffler DA. The present and the future in the diagnosis and management of celiac disease. Gastroenterol Rep. 2015;3:3-11.

40. Lammi A, Arikoski P, Hakulinen A, Schwab U, Uusitupa M, Heinonen S, et al. Development of gliadin-specific immune responses in children with HLAassociated genetic risk for celiac disease. Scand J Gastroenterol. 2016;51: 168-77.

41. Haller MJ, Schatz DA. The DIPP project: 20 years of discovery in type 1 diabetes. Pediatr Diabetes. 2016;17:5-7.

42. Parizade M, Shainberg B. Positive Deamidated Gliadin Peptide Antibodies and Negative Tissue Transglutaminase IgA Antibodies in a Pediatric Population: To Biopsy or Not To Biopsy. Clin Vaccine Immunol CVI. 2010;17:884-6.

43. Olen O, Gudjónsdóttir AH, Browaldh L, Hessami M, Elvin K, Liedberg A-S, et al. Antibodies against deamidated gliadin peptides and tissue transglutaminase for diagnosis of pediatric celiac disease. J Pediatr Gastroenterol Nutr. 2012;55: 695-700.

44. Barbato M, Maiella G, Di Camillo C, Guida S, Valitutti F, Lastrucci G, et al. The anti-deamidated gliadin peptide antibodies unmask celiac disease in small children with chronic diarrhoea. Dig Liver Dis Off J Ital Soc Gastroenterol Ital Assoc Study Liver. 2011:43:465-9.

45. Megiorni F, Mora B, Bonamico M, Barbato M, Nenna R, Maiella G, et al. HLADQ and risk gradient for celiac disease. Hum Immunol. 2009;70:55-9.

46. Carroccio A, lacono G, Montalto G, Cavataio F, Di Marco C, Balsamo V, et al. Exocrine pancreatic function in children with coeliac disease before and after a gluten free diet. Gut. 1991;32:796-9.

47. Nousia-Arvanitakis S, Fotoulaki M, Tendzidou K, Vassilaki C, Agguridaki C, Karamouzis M. Subclinical Exocrine Pancreatic Dysfunction Resulting From Decreased Cholecystokinin Secretion in the Presence of Intestinal Villous Atrophy: J. Pediatr Gastroenterol Nutr. 2006:43:307-12.

48. Nousia-Arvanitakis S, Karagiozoglou-Lamboudes T, Aggouridaki C, MalakaLambrellis E, Galli-Tsinopoulou A, Xefteri M. Influence of Jejunal Morphology Changes on Exocrine Pancreatic Function in Celiac Disease. J Pediatr Gastroenterol. 1999:29:81-5.

49. Kelly T, Buxbaum J. Gastrointestinal Manifestations of Cystic Fibrosis. Dig Dis Sci. 2015;60:1903-13.

50. Whitcomb DC, Lowe ME. Human pancreatic digestive enzymes. Dig Dis Sci. 2007:52:1-17

51. Rana SS, Dambalkar A, Chhabra P, Sharma R, Nada R, Sharma V, et al. Is pancreatic exocrine insufficiency in celiac disease related to structural alterations in pancreatic parenchyma? Ann. Gastroenterol Q Publ Hell Soc Gastroenterol. 2016;29:363-6.

52. Zelnik N. Neurologic Disorders in Patients With Celiac Disease: Are They Mediated by Brain Perfusion Changes?: In Reply. Pediatrics. 2004;114:1734.

53. Black MM. The evidence linking zinc deficiency with children's cognitive and motor functioning. J Nutr. 2003;133:1473S-6S.

54. Aronsson CA, Lee H-S, Liu E, Uusitalo U, Hummel S, Yang J, et al. Age at Gluten Introduction and Risk of Celiac Disease. Pediatrics. 2015;peds:2014-1787. 